\title{
Immunomodulator Testing on Ethanol Extract of Gynura procumbens Leaves to Mus musculus Adaptive Immune System: in Vitro Study
}

\author{
Dinia Rizqi Dwijayanti and Muhaimin Rifa'i* \\ Department of Biology, Faculty of Mathemathic and Natural Sciences, University of Brawijaya, Malang, \\ Indonesia
}

\begin{abstract}
Immunomodulator is a substance that has an ability to modulate the activity and function of immune system. Gynura procumbens supposed to has benefit as an immunomodulator because of it afficacy to cure many diseases. The aim of this study is to determine the effect and dose variations of $G$. procumbens extract on biological aspect of $C D 4^{+} C D 62 L^{-}$, $\mathrm{CD}^{+}{ }^{+} \mathrm{CD} 62 \mathrm{~L}^{+}, \mathrm{CD} 8{ }^{+} \mathrm{CD} 62 \mathrm{~L}^{-}$and $\mathrm{CD} 8{ }^{+} \mathrm{CD} 62 \mathrm{~L}^{+} \mathrm{T}$ cells. G. procumbens extract concentrations that used in this experiment were $0 \mu \mathrm{g} / \mathrm{ml}, 0.1 \mu \mathrm{g} / \mathrm{ml}, 1 \mu \mathrm{g} / \mathrm{ml}$, and $10 \mu \mathrm{g} / \mathrm{ml}$. Spleen cells were cultured for 4 days in $5 \% \mathrm{CO}_{2}$ incubator at a temperature of $37^{\circ} \mathrm{C}$. Cultured cells were harvested and analyzed by flowcytometry to asses cell surface molecule expression. The resulting data were tabulated and analyzed using ANOVA analysis with a significance of $0.05 \%$ on SPSS version 16. Results showed that the extract of $G$. procumbens can increase the proliferation of $\mathrm{CD}^{+} \mathrm{CD} 62 \mathrm{~L}^{-}$, $\mathrm{CD}^{+} \mathrm{CD}_{22 \mathrm{~L}^{+}, \mathrm{CD} 8}{ }^{+} \mathrm{CD} 62 \mathrm{~L}^{-}$and $\mathrm{CD} 8{ }^{+} \mathrm{CD}_{2} 2 \mathrm{~L}^{+} \mathrm{T}$ cells compared to the control. Dose of $1 \mu \mathrm{g} / \mathrm{ml}$ showed the highest effect to promote cell activation compared with the dose of $0.1 \mu \mathrm{g} / \mathrm{ml}$ and $10 \mu \mathrm{g} / \mathrm{ml}$. Dose of $10 \mu \mathrm{g} / \mathrm{ml}$ could suppress $\mathrm{CD}^{+}{ }^{+} \mathrm{CD} 62 \mathrm{~L}^{-}, \mathrm{CD}^{+} \mathrm{CD}_{22} \mathrm{~L}^{+}, \mathrm{CD}^{+} \mathrm{CD} 62 \mathrm{~L}^{-}$and $\mathrm{CD}^{+} \mathrm{CD} 2 \mathrm{~L}^{+} \mathrm{T}$ cells development. This study suggests that the ethanol extract of $G$. procumbens has benefit as an immunomodulator and involved in the immune system.
\end{abstract}

Keywords: Gynura procumbens, immunity, immunomodulator, in vitro, lymphocytes.

\section{INTRODUCTION}

Immunomodulator is a substance that has an ability to modulate the activity and function of the immune system. Immunomodulator has ability to influence the number of cells that play role in the adaptive immune system such as $\mathrm{CD} 4^{+}$ and $\mathrm{CD} 8^{+} \mathrm{T}$ cells. Research on immunomodulator that has been done used the recombinant cytokines. Recombinant cytokines that were used were interferon- $\nu$ (IFN- $\gamma$ ) in combination with vaccines [1,2]. The weakness of this substance are unstable, easily degraded, and have negative effects such as neutrophilia or defective neutrophil function, lymphophenia and monocytophenia [3]. Based on that case, we need another alternative such as active compound in a plant that has immunomodulator activity. One of them is Gynura procumbens or Sambung Nyawa.

G. procumbens has been long used by people in Java as a traditional medicine. Based on recent studies, leaves of $G$. procumbens have a lot functions such as anti-cancer, anti-inflammation of the kidneys and as anti-diabetic [4]. The

\footnotetext{
* Correspondence address:

Muhaimin Rifa'i

Email : rifa123@ub.ac.id

Address : Laboratory of Animal Physiology, University of Brawijaya, Jl. Veteran, Malang, 65145
}

immunological side $G$. procumbens such as immunomodulator activity has not been studied yet. In fact, with so many functions of $G$. procumbens, it is possible that these plants have immunomodulator capabilities that can affect the activity of immunocompetent cells such as $\mathrm{CD}^{+} \mathrm{CD} 2 \mathrm{~L}^{-}, \mathrm{CD} 4{ }^{+} \mathrm{CD} 62 \mathrm{~L}^{+}, \mathrm{CD} 8^{+} \mathrm{CD} 62 \mathrm{~L}^{-}$and $\mathrm{CD}^{+} \mathrm{CD}^{2} \mathrm{~L}^{+} \mathrm{T}$ cells. This study aimed to determine the effect of $G$. procumbens and dose variations of $G$. procumbens extract on the number of $\mathrm{CD}^{+} \mathrm{CD} 2 \mathrm{~L}^{-}, \mathrm{CD} 4^{+} \mathrm{CD} 2 \mathrm{~L}^{+}, \mathrm{CD} 8^{+} \mathrm{CD} 2 \mathrm{~L}^{-}$ and $\mathrm{CD}^{+} \mathrm{CD}^{+} \mathrm{L}^{+} \mathrm{T}$ cells.

\section{MATERIALS AND METHODS \\ Medium Preparation}

Culture medium that was used in this study was RPMI medium with antibiotics penicillin and streptomycin. The medium were put in 2 propylene tubes, each as much as $5 \mathrm{ml}$ and used as control medium. $G$. procumbens extract powder weighed $0.2 \mathrm{gr}$ and diluted with $200 \mathrm{ml}$ of sterile water and then homogenized. Then, a stock solution with a concentration of $1 \mathrm{mg} / \mathrm{ml}$. $100 \mu \mathrm{l}$ was diluted with $9900 \mu \mathrm{l}$ control medium to obtain a dose of 3 medium with a concentration $10 \mu \mathrm{g} / \mathrm{ml}$. $500 \mu \mathrm{l}$ dose in 3 medium was diluted with of $4500 \mu \mathrm{l}$ control medium to obtain a dose 2 medium with a concentration 1 $\mu \mathrm{g} / \mathrm{ml} .500 \mu \mathrm{l}$ dose 2 medium was diluted with of $4500 \mu \mathrm{l}$ control medium to obtain a dose 1 
(Dwijayanti and Rifa'i)

medium with a concentration $0.1 \mu \mathrm{g} / \mathrm{ml}$. Dose 1 , 2 , and 3 medium filtered with cell strainer (Millipore membrane) and transferred into a new propylene tube. After filtered, 4 types of medium were added with $1 \mu$ of 2-mercaptoethanol, $10 \%$ Fetal Bovine Serum (FBS), and $1 \% \alpha-C D 3$.

\section{Cell Isolation and Counting}

Spleen organ was isolated from mice. Spleen was washed in petri dish that contained PBS. The spleen was transferred to another petri dish which also contained PBS, and then crushed. The suspension was filtered and transferred into propylene tube, then added with PBS until $12 \mathrm{ml}$ suspension. Suspension of cell was centrifuged with a speed of $2500 \mathrm{rpm}$ for 5 minutes at $4^{\circ} \mathrm{C}$. Pellet resuspended in $1 \mathrm{ml}$ of control medium. This suspension taken $20 \mu \mathrm{l}$ and added with $80 \mu \mathrm{l}$ evans blue and then homogenized by pipetting. The number of cells was counted with haemocytometer.

\section{Cell culture}

Each medium, i.e. control, dose $10 \mu \mathrm{g} / \mathrm{ml}, 1$ $\mu \mathrm{g} / \mathrm{ml}$, and $0.1 \mu \mathrm{g} / \mathrm{ml}$ were added with $\pm 122 \mu \mathrm{l}$ of cell suspension and mixed gentle. Each of these medium which contain cell was inserted into the well in plate. The cells were incubated in a $5 \% \mathrm{CO}_{2}$ incubator at $37^{\circ} \mathrm{C}$ for 4 days. After 4 days, the cells were harvested and then centrifuge with a speed of $2500 \mathrm{rpm}$ for $5 \mathrm{~min}$ at $4^{\circ} \mathrm{C}$. Pellet was resuspended in $1 \mathrm{ml}$ PBS. Each sample was taken $20 \mu \mathrm{l}$ and added with $80 \mu \mathrm{l}$ evans blue after that was homogenized by pipetting to count the number of cells. Each sample was also taken $300 \mu \mathrm{l}$ and transferred into micro tube containing $500 \mu \mathrm{l}$ PBS. A sample in 3 micro tubes was centrifuged with a speed of $2500 \mathrm{rpm}$ for 5 minutes at $4^{\circ} \mathrm{C}$. Pellet stained with antibodies with extracellular staining.

\section{Flowcytometry Test}

Pellet in micro tube was added with $50 \mu \mathrm{l}$ antibody. Antibodies that were used were FITCconjugated rat anti-mouse CD4, PE-conjugated rat anti-mouse $\mathrm{CD} 8$, and $\mathrm{PE} / \mathrm{Cy} 5$-conjugated rat anti-mouse CD62L. After that, the samples were homogenized by pipetting and incubated in the ice box for 20 minutes. Each sample in a micro tube was transferred to the flowcytometry cuvettes and added with $300 \mu \mathrm{l}$ PBS. Next, the samples were ready for running with flowcytometer.

\section{Experimental Design and Data Analysis}

The design of this study was experimental research with a completely randomized design consist of 4 treatments (control, dose $10 \mu \mathrm{g} / \mathrm{ml}, 1$ $\mu \mathrm{g} / \mathrm{ml}$, and $0.1 \mu \mathrm{g} / \mathrm{ml}$ ). Flowcytometry results were visualized using BD CellQuest PRO $^{\text {TM }}$ software then the resulting data were tabulated and analyzed using ANOVA analysis with a significance of $0.05 \%$ on SPSS version 16 .

\section{RESULT AND DISCUSSION Population of $\mathrm{CD}^{+} \mathrm{CD}^{+} 2 \mathrm{~L}^{-}$and $\mathrm{CD}^{+}{ }^{+} \mathrm{CD} 62 \mathrm{~L}^{+} \mathrm{T}$ Cells}

Extract of $G$. procumbens with 4 different doses gave significant different results on the activation of $\mathrm{CD}^{+} \mathrm{T}$ lymphocytes (Fig. 1). Control treatment $0 \mu \mathrm{g} / \mathrm{ml}$ indicated the relative numbers of $\mathrm{CD}^{+}{ }^{+} \mathrm{CD} 62 \mathrm{~L}^{-} \mathrm{T}$ cells were $23.91 \%$, and the absolute numbers of cells were $5376 \times 10^{3}$ cells. Dose of $0.1 \mu \mathrm{g} / \mathrm{ml}$ in cell culture showed greater cell numbers compared with control with relative number $29.54 \%$ as many $17015.1 \times 10^{3}$ cells. Dose of $1 \mu \mathrm{g} / \mathrm{ml}$ showed the highest absolute number of 4 treatments given with the absolute number $30272.5 \times 10^{3}$ cells $(39.41 \%)$. The absolute numbers of cells in a $10 \mu \mathrm{g} / \mathrm{ml}$ dose were $9301 \times 10^{3}$ cells $(37.67 \%)$. This number was decreased compared to dose $0.1 \mu \mathrm{g} / \mathrm{ml}$ and 1 $\mu \mathrm{g} / \mathrm{ml}$, but still higher than the control.

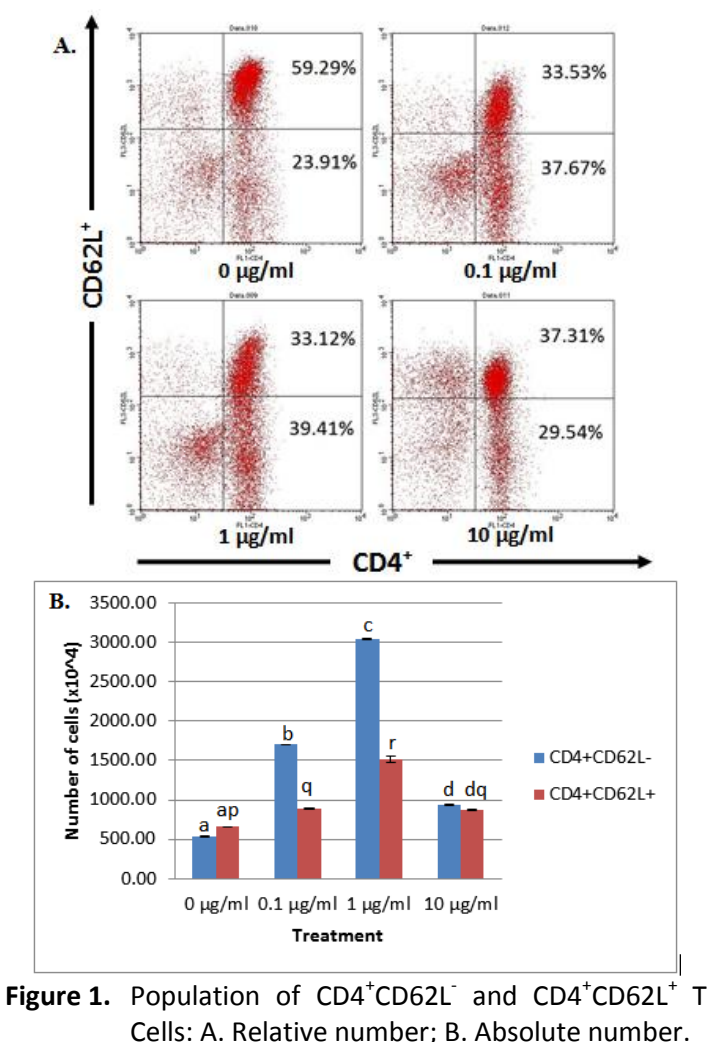


Ethanol extract of $G$. procumbens was also affected the proliferation of $\mathrm{CD} 4{ }^{+} \mathrm{CD} 62 \mathrm{~L}^{+} \mathrm{T}$ cells. The relative numbers of the cells in the control treatment were $52.29 \%$ and the absolute numbers were $6551.2 \times 10^{3}$ cells. Relative numbers of $\mathrm{CD}^{+}{ }^{+} \mathrm{CD} 62 \mathrm{~L}^{+} \mathrm{T}$ cells in the $0.1 \mu \mathrm{g} / \mathrm{ml}$ dose of the extract were $37.31 \%$ and the absolute numbers were $8822.5 \times 10^{3}$ cells. The relative numbers of cells in the $1 \mu \mathrm{g} / \mathrm{ml}$ dose treatment were $33.12 \%$ with the absolute numbers $15164.6 \times 10^{3}$ cells. Treatment dose of 10 $\mu \mathrm{g} / \mathrm{ml}$ showed the relative number of $33.53 \%$ with the absolute number $8733.7 \times 10^{3}$ cells.

The pattern of $\mathrm{CD}^{+}{ }^{+} \mathrm{CD} 62 \mathrm{~L}^{-} \mathrm{T}$ cell proliferation showed the same trend with the proliferation of $\mathrm{CD} 4{ }^{+} \mathrm{CD} 62 \mathrm{~L}^{+} \mathrm{T}$ cells. The number of cells increased at treatment doses $0.1 \mu \mathrm{g} / \mathrm{ml}, 1 \mu \mathrm{g} / \mathrm{ml}$ and 10 $\mu \mathrm{g} / \mathrm{ml}$ compared to the control treatment. Dose $1 \mu \mathrm{g} / \mathrm{ml}$ showed the highest cell number compared to other treatments. The number of cells decreased in a dose of $10 \mu \mathrm{g} / \mathrm{ml}$ when compared to dose $0.1 \mu \mathrm{g} / \mathrm{ml}$ and $1 \mu \mathrm{g} / \mathrm{ml}$. Comparison of the number of $\mathrm{CD}^{+}{ }^{+} \mathrm{CD} 62 \mathrm{~L}^{-} \mathrm{T}$ cells and $\mathrm{CD}^{+}{ }^{+} \mathrm{CD} 62 \mathrm{~L}^{+} \mathrm{T}$ cell can be seen clearly that in the control treatment $\mathrm{CD}^{+}{ }^{+} \mathrm{CD} 62 \mathrm{~L}^{+} \mathrm{T}$ cell count more than $\mathrm{CD}^{+}{ }^{+} \mathrm{CD} 62 \mathrm{~L}^{-} \mathrm{T}$ cells, while cells after treatment with the $G$. procumbens extract given, the number of $\mathrm{CD}^{+} \mathrm{CD}^{+} 2 \mathrm{~L}^{+} \mathrm{T}$ cells tend to decrease compared to $\mathrm{CD}^{+} \mathrm{CD}^{-} 2 \mathrm{~L}^{-} \mathrm{T}$ cells. $\mathrm{CD} 62 \mathrm{~L}$ was a molecule that is owned by the naive cells [5]. It showed that extracts of $G$. procumbens has the ability to activate $\mathrm{CD} 4{ }^{+} \mathrm{T}$ cells so $\mathrm{CD} 4^{+} \mathrm{CD} 62 \mathrm{~L}^{+}$ $\mathrm{T}$ cells lose $\mathrm{CD} 62 \mathrm{~L}$ molecule into $\mathrm{CD}^{+}{ }^{+} \mathrm{CD} 62 \mathrm{~L}^{-} \mathrm{T}$ cells.

The increase of activated $\mathrm{CD} 4^{+} \mathrm{T}$ cells number after the administration of extracts $G$. procumbens supposedly because the content of flavonoids and saponin in G. procumbens as an immunostimulant. According to Middleton et al. [6], flavonoids have the ability to trigger the activity of MAP Kinase. Mitogen can stimulate the increase of IL-2. IL-2 is a proliferation and differentiation factor of immunocompetent cells. Concentration of cyclin D2 and cyclin E would have increased when the cells were exposed to IL-2. IL-2 was also served to inhibit the p27 concentration. Under these conditions, IL-2 was able to induce cell cycle continuation of the $\mathrm{G} 1$ phase to the $S$ phase of the cell cycle so it proliferated actively [7]. Saponin has the ability to increase cytokine IFN $\gamma$ [8]. Lee et al. [9] and Shi et al. [10] mentioned that IFN $\gamma$ can stimulate the up-regulation of MHC-II expression so that more $\mathrm{T}$ cells differentiate into $\mathrm{CD} 4^{+} \mathrm{T}$ cells.

The decrease of the number of cells in the dose 3 treatment showed that $G$. procumbens at a dose of $10 \mu \mathrm{g} / \mathrm{ml}$ have immunosuppressive effects on $\mathrm{CD}^{+} \mathrm{T}$ cells. This immunosuppressive effect was also obtained from the ethanol extract of leaf flavonoids in G. procumbens. According to Schroeter et al. [11], the actions of flavonoids were very complex, sometimes synergistic and antagonistic at times depend on the specific components, cell type, concentration, and experimental design. Based on this statement, it can be seen that the concentration of flavonoids in the given doses influenced the cells. Immunosuppressant tends to inhibit the transcription of cytokines so the numbers of cytokines such as IL-2 and IFN $\gamma$ that play role in cell activation were decreasing [5].

\section{Population of $\mathrm{CD}^{+} \mathrm{CD}^{-} \mathrm{L}^{-}$and $\mathrm{CD}^{+} \mathrm{CD}^{+} 2 \mathrm{~L}^{+} \mathrm{T}$ Cells}

Extract of $G$. procumbens in cell cultures influence the activation of $\mathrm{CD}^{+} \mathrm{T}$ lymphocytes (Fig. 2). The relative numbers of $\mathrm{CD}^{+} \mathrm{CD} 62 \mathrm{~L}^{-} \mathrm{T}$ cells in a control treatment were $4.04 \%$ and absolute number of cells $2421.1 \times 10^{3}$ cells. Treatment with the $G$. procumbens ethanol extract showed the higher proliferation compared with control treatment. The numbers of cells in dose 1 treatment were $4584.6 \times 10^{3}$ cells (4.70\%), dose 2 were $7767.5 \times 10^{3}$ cells (3.38\%), and dose 3 were $3518.2 \times 10^{3}$ cells (2.93\%). Same with $\mathrm{CD}^{+} \mathrm{T}$ cells, a dose 2 also showed the highest proliferation ability of the $\mathrm{CD} 8^{+} \mathrm{T}$ cells.

Extract of $\mathrm{G}$. procumbens cell culture also affect proliferation of $\mathrm{CD}^{+} \mathrm{CD}_{2} \mathrm{~L}^{+} \mathrm{T}$ cell. The relative number of $\mathrm{CD}^{+} \mathrm{CD}_{22 \mathrm{~L}^{+}} \mathrm{T}$ cells in the control treatment were $2.07 \%$ and the absolute number were $404 \times 10^{3}$ cells. The dose $0.1 \mu \mathrm{g} / \mathrm{ml}$ treatment showed the relative number of cells $3.31 \%$ and the absolute number were $615.5 \times 10^{3}$ cells. At a dose $1 \mu \mathrm{g} / \mathrm{ml}$, the relative number of cells $2.63 \%$ was as many $1029.1 \times 10^{3}$ cells. While at a dose $10 \mu \mathrm{g} / \mathrm{ml}$, the relative number of cells $1.95 \%$ was as many $292.8 \times 10^{3}$ cells. These results indicated that proliferation of $\mathrm{CD}^{+} \mathrm{CD}_{2} \mathrm{~L}^{+} \mathrm{T}$ cell was higher in the treatment with the $G$. procumbens extract dose $0.1 \mu \mathrm{g} / \mathrm{ml}$ and dose 1 $\mu \mathrm{g} / \mathrm{ml}$, while the dose $10 \mu \mathrm{g} / \mathrm{ml}$ cell number decreased compared to the control.

The increase in $\mathrm{CD} 8^{+} \mathrm{T}$ cells was affected by the increase in cytokines IL-2 and IFN $\gamma$ that 
induced flavonoid and saponin in G. procumbens extracts as described previously. The increase of $\mathrm{CD}^{+} \mathrm{T}$ cells were also influenced by $\mathrm{CD} 4^{+} \mathrm{T}$ cells that activated because $\mathrm{CD}^{+} \mathrm{T}$ cells that were activated would be differentiated into Th1 that producing IL 2 and IFN- $\gamma$ [12]. Dose $10 \mu \mathrm{g} / \mathrm{ml}$ provides suppressive effect on $\mathrm{CD}^{+} \mathrm{T}$ cells because this dose also has suppressive effects on $\mathrm{CD} 4^{+} \mathrm{T}$ cells. IL-2 that produced by $\mathrm{CD} 4^{+} \mathrm{T}$ cells as addition used for the up-regulation itself and itwas also used by $\mathrm{CD}^{+} \mathrm{T}$ cells as a stimulant for proliferation. It is explained further that the $C D 8^{+}$ $T$ cells have a higher affinity than the affinity of CD4 ${ }^{+} \mathrm{T}$ cells in the use of IL-2 [12].

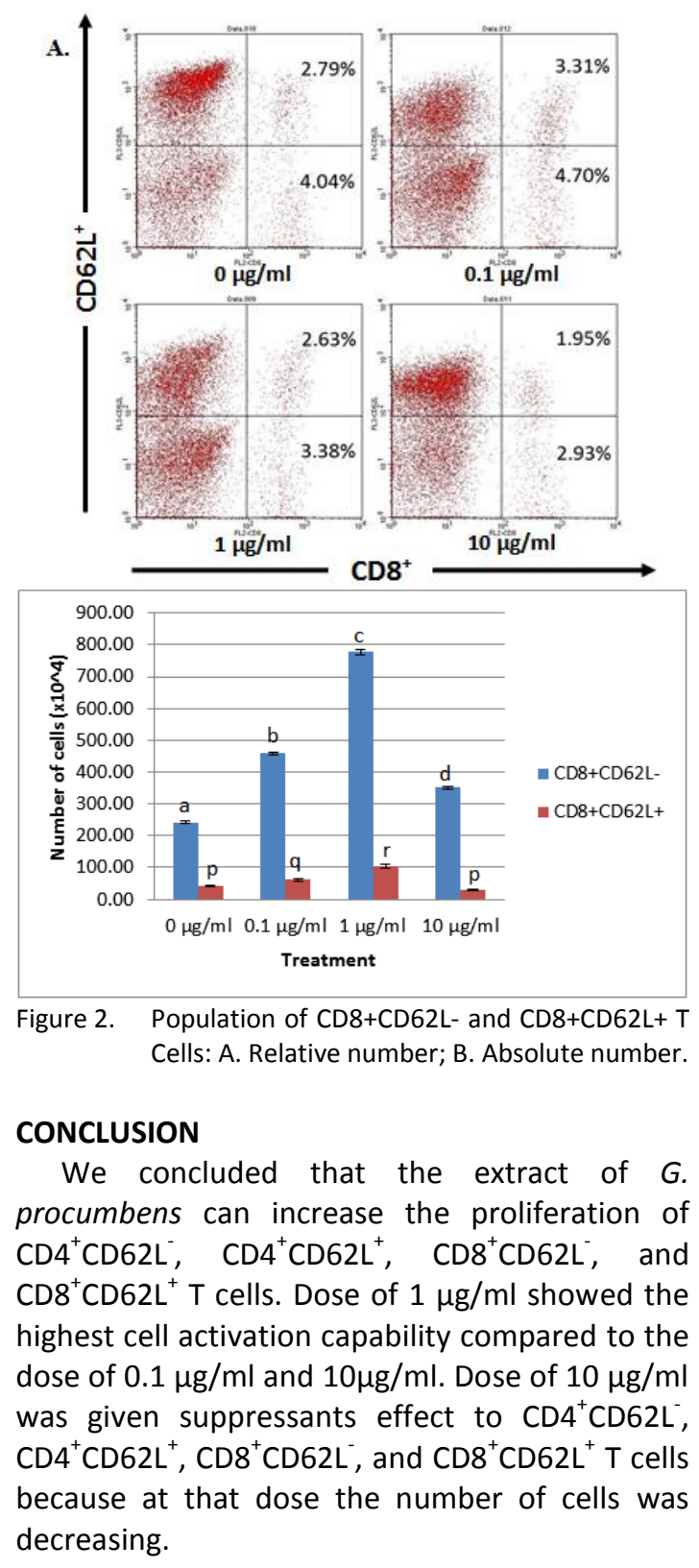

\section{ACKNOWLEDGEMENT}

The first author thanks to Muhaimin Rifa'i, S.Si., PhD.Med.Sc., as the supervisor of this research. We also thank Widodo, S.Si., M.Si, PhD.Med.Sc., DR. Ir. Sasmito Djati, MS and Drs. Aris Soewondo, M.Si. as the reviewers of this paper. Thank is also delivered to Indriya R., Dewi S., S.Si., M.Si., Ahmad Sony, S.Si., M.Si., Bambang P., S.Si., and Uwais A.Q., S.Si. for supporting me in this research.

\section{REFERENCES}

[1] Anderson, K.P., E.H. Fennie, and T. Yilmo. 1989. Enhancement of a secondary antibody response to vesicular stomatitis virus $G$ protein by IFN- $\gamma$ treatment at primary immunization. Immun. 140. 35993604.

[2] Cao, M., O. Sasaki, A. Yamada, and J. Imanishi. 1992. Enhancement of the protective effect of inactivated influenza virus vaccine by Cytokines. Vaccine. 10. 238 $-242$.

[3] Lowenthal, J.W., B. Lambrecht, T.P. van Den Berg, M.E. Andrew, A.D.G. Strom, and A.G. D. Bean. 2000. Avian Cytokines-the natural approach to therapeutics. Developmental and Comparative Immunology. 24. 355-365.

[4] Nugroho, Y. A., B. Wahjoedi, and A. Chozin. 1997. Information of Pharmacology and Phytochemical research of Gynura procumbens (Lour.) Merr. Proceeding of National Seminar of Indonesian Herbal XII.

[5] Rifa'i, M. 2011. Imunology and Bioregulator. UB Press. Malang.

[6] Middleton, E., C. Kandaswami, and T.C. Theoharides. 2000. The effects of plant Flavonoids on mammalian cells: implications for inflammation, heart disease, and cancer. Pharmacol. 52. 673751.

[7] Fathir, A. 2013. Immunity modulation of Mus musculus infected with Salmonella thypi after the induction of Moringa oleifera Lam. leaves extract. Master Thesis. Department of Biology, University of Brawijaya. Malang.

[8] Cheeke, P.R. 2000. Actual and potential aplication of Yucca schidigere and Quillaja saponaria Saponin in human and animal nutrition. Anim Sci. 77. 1-10.

[9] Lee, Y.H., Y.Ishida, M. Rifa'i, Z. Shi, K. Isobe, and $H$. Suzuki. 2008. Essential role of CD8+CD122+ regulatory $T$ cells in the 
recovery from experimental autoimmune encephalomyelitis. Immunology. 180. 825832.

[10] Shi, Z., M. Rifa'i, Y.H. Lee, H. Shiku, K. Isobe, and $H$. Suzuki. 2008. Importance of CD80/CD86-CD28 interactions in the recognition of target cells by $\mathrm{CD} 8+\mathrm{CD} 122+$ regulatory T cells. Immunology. 124. 121128.

[11] Schroeter H., C. Boyd, J.P.E. Spencer, R.J. Williams, E. Cadenas, C. Rice-Evans. 2002. MAPK Signaling in neuro degeneration: influences of Flavonoids and of nitric oxide. Neurobiology of Aging. 23. 861-880.

[12] Rifa'i, M., Z. Shi, S.Y. Zhang, Y.H. Lee, H. Shiku, K. Isobe, and H. Suzuki. 2008. CD8+CD12+ regulatory $T$ cells recognize activated $\mathrm{T}$ cells via conventional $\mathrm{MHC}$ class I- $\alpha \beta T C R$ interaction and become IL-10producing active regulatory cells. International immunology. 20. 937-947. 